\title{
Reliability and validity of the Japanese version of the Recovery-Stress Questionnaire for Athletes 76
}

\author{
Susumu Kadooka ${ }^{1}$, Shiori Horisawa ${ }^{2}$, Masanobu Araki ${ }^{3}$ and Takayuki Sugo ${ }^{4}$ \\ ${ }^{1}$ 金沢星稜大学人間科学部， =920-8620 石川県金沢市御所町丑 10 番地 1 (Faculty of Human Science, Kanazawa Seiryo \\ University, 10-1 Ushi, Gosho-machi, Kanazawa, Ishikawa 920-8620, Japan) \\ 2 慶應義塾大学医学部スポーツ医学総合センター, † 160-8582 東京都新宿区信濃町 35 (Institute for Integrated Sports Med- \\ icine, Keio University School of Medicine, 35 Shinanomachi, Shinjuku-ku, Tokyo 160-8582, Japan) \\ ${ }^{3}$ 日本福祉大学スポーツ科学部， T470-3295 愛知県知多郡美浜町大字奥田字会下前 35-6 (Faculty of Sport Sciences, Nihon \\ Fukushi University, 35-6 Aza-Egemae, Ooaza-Okuda, Mihama-cho, Chita-gun, Aichi 470-3295, Japan) \\ ${ }^{4}$ 大阪体育大学体育学部，７590-0496 大阪府泉南郡熊取町朝代台 1-1 (Osaka University of Health and Sport Sciences, 1-1 \\ Asashirodai, Kumatori, Sennan, Osaka 590-0496, Japan)
}

Received: December 26, 2017 / Accepted : January 10, 2019

\begin{abstract}
Kellmann and Kallus (2011) have developed a scale for evaluating recovery, which is named "The Recovery-Stress Questionnaire for Athletes (RESTQ-76 Sport)." This scale has contributed to the remarkable development of sport psychological studies on recovery and has been translated into various languages in different countries. Moreover, it has been used as an index for providing scientifically derived support for athletes participating in world championship events and Olympic games. The usefulness of this scale has been empirically supported. However, a Japanese version of RESTQ-76 Sport has not been developed to date. The Japanese version of RESTQ-Sport 76 was developed, and its reliability and validity were examined as a new index for monitoring in athletes. Participants were university and high school students $(\mathrm{N}=681,424$ men and 257 women, aged $=15-23)$ participating in athletic clubs and doing sports daily. Cronbach's $\alpha$ was calculated to examine the internal consistency. Moreover, principal factor analysis with varimax rotation was conducted to examine the reproducibility of the factor structure, and correlation analysis was conducted with the Japanese version of POMS-S for examining the concurrent validity of the scale. The results indicated that the Japanese version of RESTQ-76 Sport had adequate reliability and validity that was similar to the original version, which supported Kellmann and Kallus (2001). In the future, this scale is expected to be a new index for evaluating the balance between stress and recovery in athletes.
\end{abstract}

Jpn J Phys Fitness Sports Med, 68(2): 133-143 (2019)

Keywords : stress, recovery, assessment, reliability, validity

\section{緒言}

「休養も練習のうち」という言葉があるように，アス リートのパフォーマンス向上の促進又はパフォーマンス の低下を防ぐためにもリカバリーを計画的に導入してい くことは重要である。慢性的ストレスの結果生じる様々 な問題（ex. バーンアウト，ドロップアウト）の原因は, 近年ストレスというよりは寧ろリカバリー不足にあると 指摘されるようになってきた"1)。リカバリーとは,「パ フォーマンス能力を再構築するための個人間及び個人内 の多階層 (ex. 心理的, 生理的, 社会的) 過程」光と定義さ れる。また, リカバリーには「対処資源を補充, 増加さ
せるため，そしてコンディションを最適化するための自 発的な活動や行動（積極的リカバリー）も含まれる」と されている、リカバリーの研究は, 睡眠, 栄養, サプ リメント, 冷却・温熱療法, マッサージ, ストレッチ, コンプレッション衣類, 水浴, 瞑想など多岐に渡る ${ }^{3,4)}$.

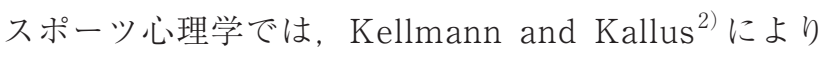
The Recovery-Stress Questionnaire for Athletes (以下, RESTQ-76 Sport）というリカバリーを評価できる心理 尺度が開発され，ここ10年間余りで飛躍的にリカバリー 研究が進展した ${ }^{5)}$. RESTQ-76 Sportは, ストレス/リカ バリーの最適なバランスが最適なパフォーマンス発揮 （Individual Performance Optimum: IPO）と関連すると 
いうScissors model を背景に作成された尺度である (Fig. 1)。このモデルは，日常及び競技生活でのストレス（ $\square)$ が増加するほど, リカバリー（○）の要求 (Recovery demands）も高まるといったストレスとリカバリーの対 称関係を示したモデルである。このモデルでは主に「ス トレスとリカバリーの最適なバランスがIPOに寄与す る」「高いストレスを経験しても, 適切なリカバリーに より耐え得る対処資源を有している限り問題（ex. バー ンアウト, パフォーマンス低下）は生じない」の 2 点が 強調されている。 IPOを説明するストレス/リカバリー の関係性が丁度 “鋏み”のように見えるので, Scissors model と言われている，RESTQ-76 Sportは，既にブラ ジル，カナダ，ドイッ，エストニア，フランスなど多く の国で翻訳版が作成され使用されている5)。ストレス/ リカバリーのバランスを評価する指標としての有用性を 検討した研究には, 世界選手権やオリンピック前のコン ディショニングをモニタリングし検討されたものも幾つ かある，例えば，Kellmann et al. ${ }^{6}$ は，ボート選手を対 象にして世界選手権前の 6 週間に渡るトレーニングキャ ンプ中のストレス/リカバリーのバランスをRESTQ-76 Sportを使用して検討している。その結果，第 2 週目の 練習量が他の週と比較し最も高く，それに伴い一般的久 トレス及び感情的ストレスの得点が最も高い結果を示し たことを明らかにしている。同時に，リカバリーと関連 するフィットネス/好調な状態の得点が他の週と比較し 第 2 週目において最も低い值を示したことを報告してい る。ささらに，第 3 週目〜第 6 週目にかけて徐々に練習量 を減らしたところ，一般的ストレス及び感情的ストレス の得点が徐々に減っていき, フィットネス/好調な状態 の得点が増加したことを報告している。また，この研究 ではエルゴメータによるパフォーマンステストが実施さ れており, キャンプ後に扔いてパフォーマンス向上が認 められている. Kellmann and Günther ${ }^{7)}$ は，ボート選手 を対象に1996年のアトランタオリンピック前のストレ ス/リカバリーのバランスをモニタリングしている。そ の結果，持久系トレーニングの平均距離の増加に伴って, 活力の低下, 体調不良の訴え, フィットネス/怪我の得 点が有意に増加し, 一方フィットネス/好調な状態の得 点が有意に減少したことを報告している。このように, RESTQ-76 Sportは慢性的ストレスによる疾病の予防や 最適なパフォーマンスを発揮するための新たなモニタリ ング指標として多くの研究でその有用性が実証されつつ ある。しかし，日本版は未だ作成されて扔らず今後国内 におけるリカバリー研究を発展させていく上でも日本版 の開発は急務であると言える。

その他リカバリーを定量可能な心理尺度としては, Short Recovery and Stress Scale (SRSS) ${ }^{8,9)}$, Acute Recovery and Stress Scale (ARSS) ${ }^{8,10)}$, Recovery-Cue ${ }^{1)}$,
Perceived Recovery Status Scale (PRS) ${ }^{11)}$ が開発されて いる，RESTQ-76 Sportはそれらの尺度と比較し，「日 常生活とスポーツ特有のストレス/リカバリーを評価可 能」「ストレス/リカバリーを多面的に評価可能」「現在 のことだけでなく過去 3 日間の調整を振り返ることが可 能」という点が網羅されており，試合までの調整期間や 数日間に渡る高強度トレーニングの前後等におけるスト レス/リカバリーの指標として活用されることが期待さ れている。また，これまで心理的コンディションの指標 としては, POMS（the Profile Of Moods Scale）が頻繁 に使用されてきた ${ }^{12,13)}$. POMSはネガティブな気分 5 尺 度（緊張一不安, 抑うつ, 怒り一敵意, 疲労, 混乱) とポシ ティブな気分 1 尺度（活力）で構成されている. 中でも, 活力はリカバリーと関連する尺度であるが，リカバリー に関連する尺度が1つに限られており，POMSではリカ バリーを多面的に評価することが難しい，そこで，本研 究では日本版 RESTQ-76 Sportの作成及び信頼性・妥当 性の検証を行うことを目的とした。

\section{方 法}

調査時期と調査対象者 本研究では島本ら ${ }^{14)}$ の研究を参 考にアスリートを「サークルではなく, 運動部に所属し, 日々競技に専念している個人」と定義し，運動部に所属 し日々競技活動に専念している大学生及び高校生（15歳 〜23歳）を対象に調查を実施した，その際大学生を対象 とした調査については，書面を配付して研究の目的，方 法,データの取り扱い，個人情報保護への配慮について 丁寧に説明をして同意が得られた者を調查対象とした。 高校生に対する調查は，まず大学生と同様の説明文書に より本研究の対象となる部活動の顧問会議で説明がなさ れ，調査の承認を得た。その後，顧問教員から保護者に 対して書面により説明が行われ承認が得られた後, 各部 活動の顧問教員から高校生に質問紙が配付された。 その 際，顧問教員から高校生に対しても研究の趣旨と併せて 調査への参加は自由意志により途中で回答を辞めても良 いこと，その場合に不利益を被ることはないこと，個人 が特定されることはないこと, 回答の内容が教員に知ら れたり学校の成績に影響したりすることは一切ないこと が説明された。回答した質問紙は，速やかに封筒に入れ て厳封した後にまとめて直接筆者に提出された

調査は，2015年 3 月から 2016年 4 月の期間で実施し, 計734名の回答を得た。最終的に，久損值を有するデー 夕を除いた 681 名（男子 424 名，女子 257 名）を本研究の 分析対象者とした（有効回答率92.8\%). 分析対象者は, 硬式野球 $(n=129)$, サッカー $(n=119)$, 剣道 $(n=83)$, アルテイメット $(n=73)$, 陸上競技 $(n=67)$, ハンドボー ル $(n=63)$, バレーボール $(n=38)$ ，バスケットボール $(n=33)$, 硬式テニス $(n=30)$, バドミントン $(n=17)$, 


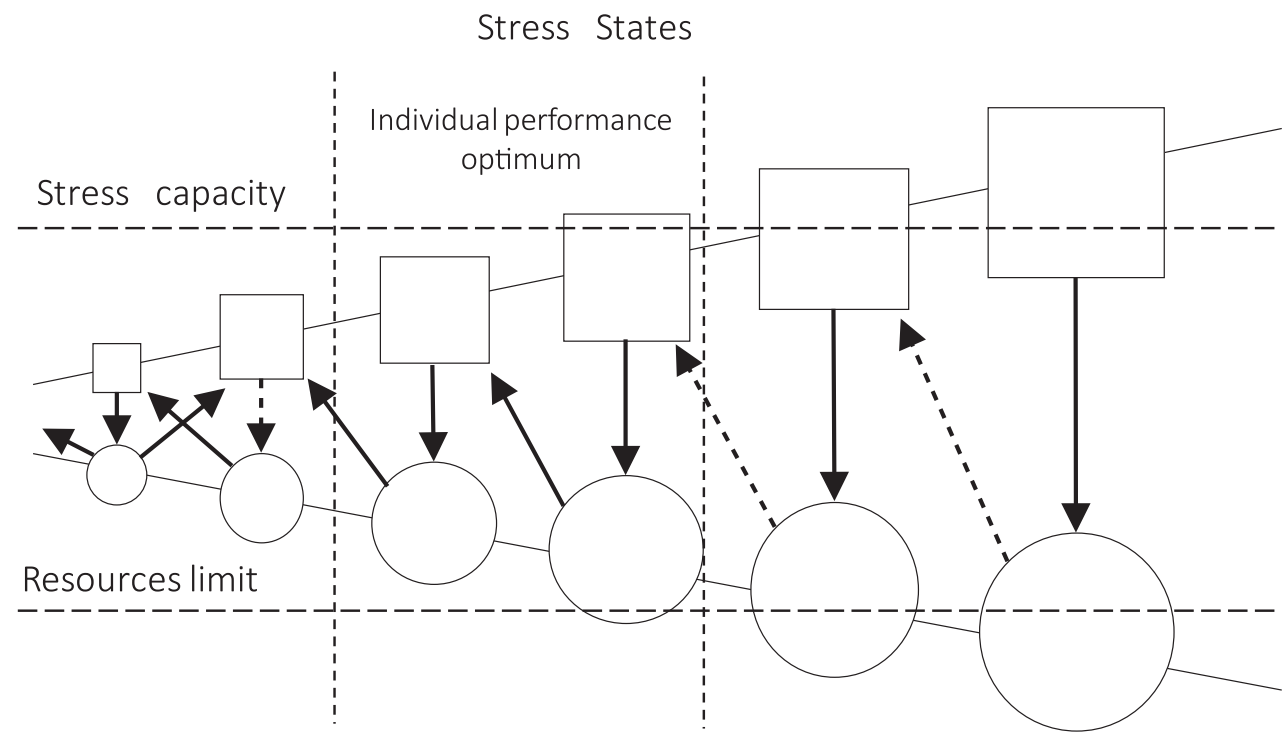

Recovery demands

Fig. 1 The "scissors-model" of the interrelation of stress-states, and recovery demands. (Kellmann and Kallus, 2001)

ソフトボール $(n=14)$ ，レスリング $(n=7)$, 体操競技 $(n=4)$ の 14 種目であった。調査対象者の平均年齢は 19.09 歳 \pm 1.72 歳であり，平均競技経験年数は 8.94 年 \pm 4.13 年であった，競技レベルは過去 2 年間の最高成績におい て, 国際大会出場 21 名, 全国大会出場377名, 地方大会 出場 124 名, 都道府県大会出場 91 名, 地区大会出場 68 名 であった。

尚, 本研究は大阪体育大学大学院の倫理委員会承認を 受けて行われた（承認番号：14-39）。

\section{調査項目}

1.フェイスシート

性別，年齢，競技種目，競技レベル，競技経験年数に ついて尋ねた。

\section{2. 日本版Recovery-Stress Questionnaire for Athletes 76 (RESTQ-76 Sport)}

RESTQ-76 Sportは，原版はドイツ語であったが他国 でも使用可能とするため, 少し遅れて英語版も開発さ れている ${ }^{2)}$ 。これらの尺度作成及び信頼性・妥当性の 手続きの詳細は, Kellmann and Kallus ${ }^{2)}$ が著したUser Manual (Human Kinetics社) にまとめられている。日本 版 RESTQ-76 Sportは英語版の項目を邦訳することで項 目を作成し，User Manual を参考に信頼性・妥当性の検 証をする手続きを進めた。

日本版 RESTQ-76 Sportを作成するにあたって原著者 のDr. Kellmannより作成の承認を得た。本研究におけ る日本版作成は次のような手順で実施した注）。第 1 に,
RESTQ-76 Sport の因子構造を Dr. Kellmannの共同研究 者として一緒に分析し本質問紙に精通する日英バイリン ガルのスポーツ心理学者 1 名, スポーツ医学の研究者 2 名, スポーツ心理学の研究者 1 名（第 1 著者）で日本語 に翻訳し項目の内容的妥当性について検討した。第 2 に, 日本語に精通した英国人の大学教員 1 名の協力を得て翻 訳された項目を英訳し（バックトランスレーション）, 第 1 著者と英国人の大学教員 1 名で英語版と意味内容に 違いがないか比較検討し修正を行った，最後に，先述の 日英バイリンガル研究者 1 名が英語版の項目と翻訳版に 意味内容の違いがないか確認し修正を行い，最終版を作 成した。

日本版 RESTQ-76 Sportは，英語版と同様一般的なス トレス尺度として 7 尺度（一般的ストレス, 感情的スト レス, 社会的ストレス, 心理的葛藤/精神的重圧, 疲労, 活 力の低下, 体調不良の訴え)，一般的なリカバリー尺度 として 5 尺度（成功, 社会的回復, 身体的回復, 全般的な 幸福度, 睡眠の質), スポーツに特有のストレス尺度と して 3 尺度（休息の妨げ, 燃え尽き/精神的な疲労困䣏, フィットネス/怪我), スポーツに特有のリカバリー尺 度として 4 尺度（フィットネス/好調な状態, 燃え尽き / 個人的達成, 自己効力感, 自己管理）の合計 19 尺度（各 尺度 4 項目，計 76 項目）により構成されている。本質問 紙は，「ここ 3 日間の行動や考えなどをどの程度の頻度

注) 本研究における翻訳作業や項目精査の手続きは，共著者で ある堀澤刑里先生が2012年度に執筆し受理された卒業論 文「日本語版Recovery-Stress Questionnaire for Athletes の作成と高校ハンドボール部員のストレス - 回復状態の 評価」(法政大学)で使用された翻訳項目をもとに行われた。 
で経験したか？」を尋ねており，各項目に対して 7 件法 （1＝全くなかった， $2=$ =とんどなかった， $3=$ ごくたま にあった， 4 =時々あった， 5 =頻繁にあった， 6 =かなり 頻繁にあった， 7 =いつもあった）により回答を求めた. Kellmann and Kallus ${ }^{2)}$ の報告をもとに, 各尺度 4 項目の 平均值を尺度得点とした。

Kellmann and Kallus ${ }^{2)}$ は, ドイツのアスリート50名を 対象に英語版 RESTQ-76 Sportの再検査信頼性を検討し ている。最初の検査日から $3 ， 4 ， 9 ， 17 ， 37$ 日後で検 討した結果, 期間が長くなるほど再検査信頼性が低下す ることを明らかにしている，特に，4 日以降は顕著な低 下がみられることから，英語版 RESTQ-76 Sportは，「こ こ 3 日間」のことについて尋ねる質問紙として使用され ている，従って，本研究に打いても「ここ 3 日間」のこ とについて尋ねる教示文とした。

\section{3. 日本版POMS-S (Japanese Short form of the Pro- file Of Moods Scale)}

日本版 RESTQ-76 sportの併存的妥当性を検証するた め, 日本版 POMS-S を外的基準とし検討した。 日本版 POMS-Sは, 全30項目 6 下位尺度（緊張一不安, 抑うつ, 怒り一敵意, 活力, 疲労, 混乱) からなる質問紙である ${ }^{13)}$. 本研究では, 対象者には 5 段階評定 $(0=$ まったくなかっ た，1＝少しあった， 2 =まあまああった， 3 =かなりあっ た，4=非常に多くあった）により，回答を求めた。ま た, 横山 ${ }^{13)}$ を参考に活気以外の 5 尺度の合計得点から活 気の得点を引いたTMD（Total Mood Disturbance）得 点をネガティブ気分の尺度得点の指標とした，日本版 POMS-Sの冒頭の教示は，これまでの先行研究 $2,6,7)$ を参 考にRESTQ-76 Sportで尋ねる期間との整合性を図るた め,「ここ 3 日間の気分を表すものについて」回答する よう教示文を修正した。

日本版 POMS-S は結果が逆氷山型（ネガティブ気分 5 尺度得点が極めて高い, ポジティブ気分 1 尺度得点が極 めて低い）の形状，RESTQ-76 SportはUnder recovery （ストレス尺度得点が極めて高い, リカバリー尺度得点が 極めて低い）を示す形状が確認されるとパフォーマンス 低下のリスクが高まるとされている ${ }^{2,15)}$. 互いにパフォー マンス低下を予測する心理尺度であることが共通してい るが, 日本版POMS-Sは気分, RESTQ-76 Sportはス卜 レス/リカバリーのレベルを扱っている点で異なってい る. RESTQ-76 Sportの併存的妥当性を検討する際，(1) RESTQ-76 Sportのストレス尺度とTMDの間に正の相 関，一方ポジティブ気分（活力）との間に負の相関を示 す(2)RESTQ-76 Sportのリカバリー尺度とポジティブ気 分 (活力) との間に正の相関，一方 TMD との間に負の 相関を示す，という仮説のもと検証を実施した。
分析 本研究では英語版 ${ }^{2}$ 作成時の手続きを参考に内 的整合性を検討するため因子ごとにCronbachの $\alpha$ 係数 を算出，因子構造の再現性を検討するため主成分分析 (varimax 回転)，併存的妥当性を検討するために日本版 POMS-S との相関分析を行った，統計分析にはすべて SPSS statics 22.0 (IBM社製)を用いて行い, 有意水準は $5 \%$ とした.

\section{結果}

日本版RESTQ-76 Sportの平均值と標準偏差 本研究の 対象者に扔ける日本版 RESTQ-76 Sport各尺度の平均值 と標準偏差をTable 1に示した。

日本版RESTQ-76 Sportの内的整合性 本質問紙の内 的整合性を確認するために，各尺度のCronbachの $\alpha$ 係 数を算出した。本研究に求いては, Kellmann and Kal$\mathrm{lus}^{2)}$ と同様に.70以上を十分な内的整合性とした。 その 結果, 一般的ストレス $(\alpha=.82)$, 社会的ストレス $(\alpha=.82)$, 全般的な幸福度 $(\alpha=.82)$, 燃え尽き/精神的な疲労困謈 $(\alpha=.80)$, 自己効力感 $(\alpha=.82)$, 自己管理 $(\alpha=.80)$, 感情的ストレス $(\alpha=.78)$, 活力の低下 $(\alpha=.70)$, 社会 的回復 $(\alpha=.74)$, フィットネス/怪我 $(\alpha=.71)$, フィッ 卜ネ久/好調な状態（ $\alpha=.74 ）$ は十分な内的整合性を示 した。理的葛藤/精神的重圧 $(\alpha=.62)$, 疲労 $(\alpha=.69)$, 体調不良の訴元 $(\alpha=.63)$ ，身体的回復 $(\alpha=.69)$ ，睡眠 の質 $(\alpha=.69)$ ，休息の妨げ $(\alpha=.67)$ ，燃元尽き/個人 的達成（ $\alpha=.64 ）$ は.60以上のやや高い内的整合性が確 認された。成功は， $\alpha=.40 て ゙$ 低い值を示した。結果は, Table 2に示した.

日本版 RESTQ-76 Sportの因子構造の再現性 Kellmann and Kallus ${ }^{2)}$ を参考に, 各個人の尺度得点を算出 した上で主成分分析（varimax 回転）により英語版と同 様の因子構造が認められるかを検討した。また，先行研 究 ${ }^{2)}$ と同様の手続きにより固有值が 1.0 以上及び累積寄 与率が 60 ～80\% となるよう主成分を採用し，因子負荷量 は.40以上を基準とした。その結果，一般的なストレス 及びリカバリー尺度（12尺度），スポーツに特有のス卜 レス及びリカバリー尺度（7 尺度）においていずれも第 1 主成分と第 2 主成分から構成される 2 次元性が認めら れた。これらについては, Kellmann and Kallus ${ }^{2)} の$ 報 告と同様の結果が示された。一般的なストレス及びリカ バリー尺度は，第 1 主成分（一般的ストレス $=.83$, 感情 的ストレス $=.85$, 社会的ストレス $=.77$, 心理的葛藤 $/$ 精 神的重圧 $=.78$, 疲労 $=.72$, 活力の低下 $=.80$, 体調不良の訴 え $=.79$ ）第 2 主成分（成功 $=.61$, 社会的回復 $=.76$, 身体 的回復 $=.77$, 全般的幸福度 $=.86$, 睡眠の質 $=.41 ）$ 共に.40 以上の高い負荷量が示された。 また，第 1 主成分の寄与 
Table 1. Mean and standard deviation of RESTQ-76 Sport in 681 athletes

\begin{tabular}{|c|c|c|c|}
\hline & Scales & Mean & $\mathrm{SD}$ \\
\hline \multirow{7}{*}{ General stress } & General Stress & 1.86 & 1.24 \\
\hline & Emotional Stress & 2.24 & 1.15 \\
\hline & Social Stress & 1.95 & 1.21 \\
\hline & Conflicts/Pressure & 2.42 & 1.08 \\
\hline & Fatigue & 2.94 & 1.15 \\
\hline & Lack of Energy & 2.26 & 1.02 \\
\hline & Physical Complaints & 2.22 & 1.08 \\
\hline \multirow{5}{*}{ General recovery } & Success & 2.21 & 0.84 \\
\hline & Social Recovery & 4.04 & 1.14 \\
\hline & Physical Recovery & 2.47 & 1.03 \\
\hline & General Well-being & 3.06 & 1.15 \\
\hline & Sleep Quality & 3.33 & 1.17 \\
\hline \multirow{3}{*}{ Sport-specific stress } & Disturbed Breaks & 2.42 & 1.20 \\
\hline & Burnout/Emotional Exhaustion & 1.59 & 1.27 \\
\hline & Fitness/Injury & 2.95 & 1.38 \\
\hline \multirow{4}{*}{ Sport-specific recovery } & Fitness/Being in Shape & 2.36 & 1.12 \\
\hline & Burnout/Personal Accomplishment & 2.14 & 0.95 \\
\hline & Self-Efficacy & 2.41 & 1.22 \\
\hline & Self-Regulation & 3.03 & 1.30 \\
\hline
\end{tabular}

Table 2. Cronbach's $\alpha$ of RESTQ -76 Sport scales $(\mathrm{N}=681)$

\begin{tabular}{clc}
\hline & \multicolumn{1}{c}{ Scales } & Cronbach $\alpha$ \\
\hline & General Stress & .82 \\
& Emotional Stress & .78 \\
& Social Stress & .82 \\
General stress & .62 \\
& Conflicts/Pressure & .69 \\
& Fatigue & .70 \\
& Lack of Energy & .63 \\
\hline \multirow{5}{*}{ General recovery } & Physical Complaints & .40 \\
& Success & .74 \\
& Social Recovery & .69 \\
& Physical Recovery & .82 \\
& General Well-being & .69 \\
\hline \multirow{5}{*}{ Sport-specific stress } & Sleep Quality & .67 \\
& Disturbed Breaks & .80 \\
& Burnout/Emotional Exhaustion & .71 \\
\hline \multirow{5}{*}{ Sport-specific recovery } & Fitness/Injury & .74 \\
& Fitness/Being in Shape & .64 \\
& Burnout/Personal Accomplishment & .82 \\
& Self-Efficacy & .80 \\
\hline
\end{tabular}


率は $41.0 \%$ ，第 2 主成分の寄与率は $21.1 \%$ ，累積寄与率 は $62.1 \%$ であった，スポーツに特有のストレス及びリカ バリー尺度は，第 1 主成分（フィットネス/好調な状態 $=.71$, 燃元尽き $/$ 個人的達成 $=.76$, 自己効力感 $=.85$, 自己 調整 $=.81$ ) 第 2 主成分（休息の妨げ $=.83$, 燃え尽き/精 神的な疲労困僙 $=.66$, フィットネス/怪我 $=.72 ）$ 共に.40 以上の高い負荷量が示された。 また, 第 1 主成分の寄与 率は $36.5 \%$, 第 2 主成分の寄与率は $26.3 \%$, 累積寄与率 は62.8\%であった。結果は, Table 3, 4に示した。

日本版RESTQ-76 Sportの併存的妥当性 併存的妥 当性を検討するため日本版 POMS-S を外的基準として Pearsonの積率相関係数を算出した（Table 5)。その結 果, RESTQ-76 Sportの一般的なストレス 7 尺度全てに おいて, POMS-SのTMD との間に中程度〜強い正の相 関（ $r=.57 \sim .76 ）$ が示された。 また，一般的なストレス 7 尺度中「一般的ストレス」「感情的ストレス」「活力の低

Table 3. Results of principal component analysis to general scales

\begin{tabular}{lccl}
\hline & Factor 1 & Factor 2 & $\mathrm{h}^{2}$ \\
\hline General Stress & $\mathbf{. 8 3}$ & .18 & .72 \\
Emotional Stress & $\mathbf{. 8 5}$ & .16 & .74 \\
Social Stress &. $\mathbf{7 7}$ & .02 & .60 \\
Conflicts/Pressure & $\mathbf{. 7 8}$ & .01 & .60 \\
Fatigue & $\mathbf{. 7 2}$ & -.08 & .52 \\
Lack of Energy & $\mathbf{. 8 0}$ & -.10 & .65 \\
Physical Complaints & $\mathbf{. 7 9}$ & -.15 & .65 \\
Success & .35 &. $\mathbf{6 1}$ & .49 \\
Social Recovery & -.11 &. $\mathbf{7 6}$ & .58 \\
Physical Recovery & -.31 &. $\mathbf{7 7}$ & .68 \\
General Well-being & -.20 & $\mathbf{. 8 6}$ & .78 \\
Sleep Quality & -.52 &. $\mathbf{4 1}$ & .44 \\
\hline eigenvalue & 4.92 & 2.53 & \\
contribution ratio(\%) & 41.0 & 21.1 & \\
\hline
\end{tabular}

下」は，POMS-Sの「活力」との間に弱い負の相関（ $r=$ -.24 .27）が認められた。一方で, RESTQ-76 Sportの 一般的なリカバリー 5 尺度中「社会的回復」「身体的回 復」「全般的幸福度」「睡眠の質」において，POMS-S の TMD との間に弱い〜中程度の負の相関 $(r=-.29 \sim .49)$ が示された。また，一般的なリカバリー 5 尺度全ては, POMS-Sの「活力」との間に弱い〜中程度の正の相関 $(r=.27 \sim .64)$ が認められた.

RESTQ-76 Sportのスポーツに特有のストレス 3 尺度 全てに打いて，POMS-SのTMD との間に弱い〜中程度 の正の相関（ $r=.28$. 53) が示された。 また，スポーツに 特有のストレス 3 尺度中「燃え尽き/精神的な疲労困供」 は, POMS-Sの「活力」との間に弱い負の相関 $(r=-.27)$ が認められた。一方で，スポーツに特有のリカバリー 4 尺度中「自己効力感」「フィットネス/好調な状態」に おいて，POMS-SのTMD との間に弱い〜中程度の負の 相関（ $r=-.24 \sim .44 ）$ が示された。また，スポーツに特有 のリカバリー4 尺度全てにおいて, POMS-Sの「活力」 との間に中程度の正の相関（ $r=.43 \sim .66 ）$ を示した。

\section{考察}

本研究は, Kellmann and Kallus ${ }^{2)}$ が作成した RESTQ-76 Sportの日本版の作成及び信頼性・妥当性の 検証を行った。

日本版 RESTQ-76 Sportの内的整合性 日本版 RESTQ-76 Sportの内的整合性を確認するために，各因 子のCronbachの $\alpha$ 係数を算出した，その結果，「一般的 ストレス」「感情的ストレス」「社会的ストレス」「活力 の低下」「社会的回復」「全般的幸福度」「燃え尽き/精 神的な疲労困䣏」「フィットネス/怪我」「フィットネス /好調な状態」「自己効力感」「自己管理」は.70以上の $\alpha$ 係数が確認されたことから，十分な内的整合性を有して いることが示唆された。一方,「心理的葛藤/精神的重圧」 「疲労」「体調不良の訴元」「成功」「身体的回復」「睡眠

Table 4. Results of principal component analysis to sport-specific scales

\begin{tabular}{lccc}
\hline & Factor 1 & Factor 2 & $\mathrm{h}^{2}$ \\
\hline Disturbed Breaks & .07 & $\mathbf{. 8 3}$ & .69 \\
Burnout/Emotional Exhaustion & .18 & $\mathbf{. 6 6}$ & .47 \\
Fitness/Injury & .26 & $\mathbf{. 7 2}$ & .59 \\
Fitness/Being in Shape & $\mathbf{. 7 1}$ & -.39 & .65 \\
Burnout/Personal Accomplishment & $\mathbf{. 7 6}$ & .18 & .61 \\
Self-Efficacy & $\mathbf{. 8 5}$ & .04 & .72 \\
Self-Regulation & $\mathbf{. 8 1}$ & .09 & .67 \\
\hline eigenvalue & 2.56 & 1.84 & \\
contribution ratio(\%) & 36.5 & 26.3 & \\
\hline
\end{tabular}


Table 5. Correlation between the RESTQ-76 Sport and TMD, Vigor scales $(n=681)$

\begin{tabular}{|c|c|c|c|}
\hline & RESTQ-sport scales & TMD & Vigor \\
\hline 1 & General Stress & $.76^{*}$ & $-.26^{*}$ \\
\hline 2 & Emotional Stress & $.75^{*}$ & $-.27^{*}$ \\
\hline 3 & Social Stress & $.64^{*}$ & $-.16^{*}$ \\
\hline 4 & Conflicts/Pressure & $.63^{*}$ & $-.13^{*}$ \\
\hline 5 & Fatigue & $.57^{*}$ & $-.16^{*}$ \\
\hline 6 & Lack of Energy & $.64^{*}$ & $-.24^{*}$ \\
\hline 7 & Psysical Complaints & $.64^{*}$ & $-.18^{*}$ \\
\hline 8 & Success & .04 & $.38^{*}$ \\
\hline 9 & Social Recovery & $-.29^{*}$ & $.47^{*}$ \\
\hline 10 & Physical Recovery & $-.48^{*}$ & $.56^{*}$ \\
\hline 11 & General Well-being & $-.44^{*}$ & $.64^{*}$ \\
\hline 12 & Sleep Quality & $-.49^{*}$ & $.27^{*}$ \\
\hline 13 & Disturbed Breaks & $.44^{*}$ & $-.08^{*}$ \\
\hline 14 & Burnout/Emotional Exhaustion & $.53^{*}$ & $-.27^{*}$ \\
\hline 15 & Fitness/Injury & $.28^{*}$ & .02 \\
\hline 16 & Fitness/Being in Shape & $-.44^{*}$ & $.66^{*}$ \\
\hline 17 & Burnout/Personal Accomplishment & $-.11^{*}$ & $.44^{*}$ \\
\hline 18 & Self-Efficacy & $-.24^{*}$ & $.47^{*}$ \\
\hline 19 & Self-Regulation & $-.09^{*}$ & $.43^{*}$ \\
\hline
\end{tabular}

の質」「休息の妨げ」「燃え尽き/個人的達成」は.70未満 の $\alpha$ 係数を示し, 内的整合性が十分でないことが示唆さ れた。

「心理的葛藤/精神的重圧」は, 項目 12 “解決してない 問題があり，気になった”，項目 18 “気持ちをオフに切 り替えられなかった”，項目 32 “人前で上手くやらなけ ればと感じた”，項目 44 “プレッシャーを感じた”の 4 項目によって構成されている。本研究に扔ける各項目の 平均値 $\pm \mathrm{SD}$ を比較すると, 項目 $12(2.54 \pm 1.66)$, 項目 $18(1.95 \pm 1.39)$, 項目 $32(2.82 \pm 1.63)$, 項目 $44(2.36 \pm 1.63)$ となった，続いて，各項目が削除された場合の $\alpha$ 係数を 確認すると項目 32( $\alpha=.49)$, 項目 $44(\alpha=.49)$, 項目 $12(\alpha$ $=.60)$, 項目 $18(\alpha=.61)$ を示した. 「心理的葛藤 $/$ 精神 的重圧」の中には項目 32 “人前で上手くやらなければと 感じた”，項目 44 “プレッシャーを感じた”など直近の試 合の有無に影響される項目が存在しており，具体的には 直近に重要な試合があると $\alpha$ 係数が増加し, 強化合宿期 間中などで直近に試合が無ければ逆に $\alpha$ 係数が減少する ことが指摘されている ${ }^{2)}$.アスリートの一般的な検討を 目指す本研究に打いては, 直近の試合の有無については 統制されていなかった，そのため，「心理的葛藤/精神的 重圧」の $\alpha$ 倸数で低值を示したと推察される.

「疲労」は，項目 2 “十分に睡眠がとれなかった”，項
目 16 “仕事や勉強で疲れた”, 項目 25 “仕事や勉強のあと, 疲労困謈の状態になった”, 項目 35 “疲れ果てた”の 4 項目によって構成されている。先行研究 ${ }^{2}$ (左) と本研 究（右）における各項目の平均值 $\pm \mathrm{SD}$ を比較すると, 項 目 $2(2.38 \pm 1.48$ vs $2.81 \pm 1.35)$, 項目 $16(2.20 \pm 1.69$ vs 3.38 $\pm 1.67)$, 項目 $25(1.71 \pm 1.66$ vs $2.58 \pm 1.71)$, 項目 35 (2.05 \pm 1.53 vs $2.99 \pm 1.62)$ となった. 続いて, 各項目が削除 された場合の $\alpha$ 係数を確認すると項目 $2(\alpha=.69)$, 項 目 16 $(\alpha=.63)$, 項目 $25(\alpha=.56)$, 項目 $35(\alpha=.59)$ を 示した. 先行研究 ${ }^{2)}$ は調查対象が16歳〜 33歳（平均 21.8 歳 \pm 3.6 ）に対し本研究では 15～23歳（平均 19.1 $\pm 1.7 ） と$ 大学生の割合が先行研究 ${ }^{2)}$ と比較し多かったことが推察 される. Carskadon ${ }^{16)}$ は，環境が自由なほど就床時刻が 遅延しがちであることを示唆しており，青年期において 生活が不規則となり易いことを報告している．竹内ら ${ }^{17)}$ は, “大学生は, 高校生までの時期や社会人と比較して, 時間的拘束が比較的緩やかで, アルバイト, サークル, クラブ，交友関係など様々なスケジュールが混在しがち である”と指摘している。また，大学生における睡眠パ タンの分類を検討した結果, 社会人と比較して不規則, 夜型睡眠型が優勢であることを報告している。本研究で はそうした大学生の不規則な睡眠習慣が, 項目 2 “十分 な睡眠がとれなかった”に影響し「疲労」の内的整合性 
を低下させたと考えられる

「成功」は項目 3 “重要な課題を済ませた”, 項目 17 “行っ たことがうまくいった”，項目41“重要な決断をした”, 項目 49 “良い考えが浮かんだ”の 4 項目によって構成さ れている. 先行研究 ${ }^{2)}$ (左) と本研究（右）に打ける各 項目の平均值 $\pm \mathrm{SD}$ を比較すると, 項目 $3 \quad(3.52 \pm 1.54 \mathrm{vs}$ $2.64 \pm 1.70)$, 項目 $17(3.48 \pm 1.32$ vs $2.64 \pm 1.11)$, 項目 41 (2.38 \pm 1.40 vs $1.48 \pm 1.45)$, 項目 $49(3.08 \pm 1.32$ vs $2.07 \pm 1.36)$ となった，続いて，各項目が削除された場合の $\alpha$ 係数を 確認すると項目 3 $(\alpha=.42)$, 項目 $17(\alpha=.32)$, 項目 $41(\alpha$ $=.31)$, 項目 $49(\alpha=.23)$ を示した。項目 3 “重要な課 題を済ませた”は一般的尺度の中の項目であることから， 授業で与えられる宿題や課題も想定されている. 大学生 の 1 週間あたりの学修時間の日米比較によれば, 日本 で最も多いのが 1 ～ 5 時間 $57.1 \%$ （アメリカは $15.3 \%$ ), アメリカで最も多いのが 11 時間以上 $58.4 \%$ （日本では 14.8\%）で日本の学修時間が顕著に少ないことが報告さ れている ${ }^{18)}$ ．このことから，日本の方が欧米に比べ学修 時間が少ないため課題を済ませたという成功を経験する ことが少なかったことが考えられる。本研究では大学生 の割合が先行研究 ${ }^{2)}$ と比較して多かったこともあり，欧 米と日本の学修への取り組みの差異が項目 3 “重要な課 題を済ませた”に影響し「成功」の内的整合性を低下さ せていたことが推察される。また，項目 41 “重要な決断 をした”，項目49“良い考えが浮かんだ”はコーチや指 導者の特性（ex. 専制的であるか民主的であるか）によっ て, 成功経験の頻度や決断を要する機会に違いがみられ, その結果 $\alpha$ 係数の変動に影響することが Kellmann and Kallus $^{2,19)}$ によって指摘されている，実際に，指導者の リーダーシップが練習時や生活全般における選手の自発 性や自主性に影響を及ぼすことが報告されており ${ }^{20,21)}$, 海外における「成功」の $\alpha$ 係数も他の尺度と比較し安定 していない（アメリカ・カナダ $\alpha=.61$, ドイツ $\alpha=.61$, ス ペイン $\alpha=.63$, ポルトガル $\alpha=.58)^{19)}$.「成功」は他の尺 度と比較して低い $\alpha$ 係数が確認されたが, 先行研究2,19) と類似した傾向が認められることからも内的整合性が低 くなる傾向を有していることが考えられる。

「燃え尽き/個人的達成」は, 項目 55 “自分のスポーツ で，やりがいのある事を成し遂げた”，項目 60 “チーム メイトが抱えている問題にうまく対処できた”，項目 70 “チームメイトの気持ちを容易に理解した”，項目 77 “自 分のスポーッで, 感情的に困難な問題に, 冷静に対処を した”の 4 項目により構成されている. 先行研究 ${ }^{2)}$ (左) と本研究（右）に打ける各項目の平均值 $\pm \mathrm{SD}$ を比較す ると，項目 $55(3.09 \pm 1.61$ vs $1.98 \pm 1.47)$ ，項目 60 (2.94 \pm 1.81 vs $1.78 \pm 1.25)$, 項目 $70(2.90 \pm 1.47$ vs $2.56 \pm 1.33)$, 項目 $77 （ 3.34 \pm 1.58$ vs $2.25 \pm 1.42 ）$ となった。続いて, 各項目が削除された場合の $\alpha$ 係数を確認すると項目 55 $(\alpha=.59)$, 項目 60 $(\alpha=.54)$, 項目 70 ( $\alpha=.54)$, 項目 77 $(\alpha$ =.60）を示した． 項目 60 “チームメイトが抱えている問 題にうまく対処できた”や項目 70 “チームメイトの気 持ちを容易に理解した”は主にチームメイトのことにつ いて尋ねる項目となっている. Kellmann and Kallus ${ }^{2,19)}$ では個人競技と集団競技でチームメイトに関する解釈が 異なるので $\alpha$ 係数を低下させる要因として項目 60 と項目 70 を挙げている（アメリカ・カナダ $\alpha=.62$, スペイン $\alpha$ $=.63$, ポルトガル $\alpha=.64)$. 一方, 高田 ${ }^{22)}$ は, 日本人青 年は西欧人青年と比較して相互独立性（ex. たいていは 自分一人で物事を決断する）が低く相互協調性（ex. 意 見が対立した時, 相手の意見を受け入れる）が高かった ことを報告している。このように日本人は，海外のアス リートと比較して個人競技，集団競技に関係なく協調性 を重んじる傾向がある，各項目が削除された場合の $\alpha$ 係 数の結果より, 日本版の「燃元尽き/個人的達成」にお いては“チームメイト”に関して問われている項目 60 , 項目70の方が寧ろ内的整合性を高くしている項目である と考えられる。一方で，項目 55 “自分のスポーッで，や りがいのある事を成し遂げた”項目 77 “自分のスポーツ で，感情的に困難な問題に，冷静に対処をした”は，主 に個人の達成について問われている項目であることから 日本版においては内的整合性を低くする項目となったと 推察される。

「体調不良の訴え」は, 項目 7 “体調がよくないと感じ た”, 項目 15 “頭痛があった”, 項目 20 “不快に感じた”, 項目 42 “肉体的に疲れ果てたと感じた”の4 項目で構成 されている. 先行研究 ${ }^{2}$ (左) と本研究 (右)に打ける 各項目の平均值 \pm SD を比較すると, 項目 7 (2.30 \pm 1.43 vs $2.34 \pm 1.51)$, 項目 $15(1.25 \pm 1.62$ vs $1.33 \pm 1.58)$, 項目 $20(1.82 \pm 1.45$ vs $2.22 \pm 1.49)$, 項目 $42(2.08 \pm 1.54$ vs 2.98 $\pm 1.72 ）$ となった，続いて，各項目が削除された場合の $\alpha$ 係数を確認すると項目 $7 \quad(\alpha=.50)$, 項目 $15(\alpha=.58)$, 項目 20 $(\alpha=.55)$, 項目 $42(\alpha=.59)$ を示した. 日本人 は仕事に対して真面目で誠実な一面がある一方，“休み 下手”であることが明らかとなっている ${ }^{23)}$ 。また, スポー ツに打いては日本の中学・高校運動部活動で過剩とも言 える練習時間や過密スケジュールなども問題となってい る ${ }^{24)}$. 実際に,「休息の妨げ」に扔ける項目 58 , 項目 66, 項目 72 は先行研究 ${ }^{2)}$ と比較し日本人を対象にした本研究 の得点のほうが高い值を示している，そうした日本人特 有の“休む”ことへの抵抗が，項目 42 “肉体的に疲机果 てたと感じた”に影響し「体調不良の訴え」の内的整合 性を低くしたと考えられる。

「身体的回復」は項目 9 “身体的リラックスをしてい ると感じた”，項目 13 “くつろいでいると感じた”，項目 29 “体調が良いと感じた”，項目 38 “何でも出来そうだと 感じた”の 4 項目によって構成されている. 先行研究 ${ }^{2)}$ 
（左）と本研究（右）における各項目の平均值 $\pm \mathrm{SD}$ を比 較すると, 項目 9 (2.99 \pm 1.43 vs $2.43 \pm 1.42)$, 項目 13 (3.02 \pm 1.41 vs $2.73 \pm 1.50)$, 項目 $29(3.09 \pm 1.55$ vs $2.84 \pm 1.43)$,

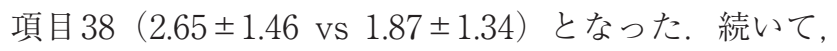
各項目が削除された場合の $\alpha$ 係数を確認すると項目 9 $(\alpha=.56)$, 項目 $13(\alpha=61)$, 項目 $29(\alpha=.62)$, 項目 38 $(\alpha=.71)$ を示した. Peters and Williams ${ }^{25}$ は, パフォー マンス遂行中に扔けるセルフトークの研究に打いて, ポ ジティブ, ネガティブ, ニュートラルの 3 つに分類して, ポジティブおよびネガティブなセルフトークの発生比率 とパフォーマンスとの関連について検討している。 その 結果, 日本人を含む東アジアの文化圈に属する人々は, ヨーロッパ系アメリカ人と比較し, ネガティブなセルフ トークが生じる比率が有意に高いこと, さらに, ネガティ ブなセルフトークの比率が高いことが, 良いパフォーマ ンスに関連するという可能性も示唆していることを報告 している。また, 有富と外山 ${ }^{26)}$ は良いパフォーマンス を発揮するために一般に言われる楽観やポジティブ思考 が，日本人のスタイルに必ずしも一致するとは限らない ことを報告している。これらパフォーマンスに対するネ ガティブな思考を持つアスリートは，それを如何にリカ バリーするかを思い描き必要な対処を行うことでより良 いパフォーマンスへと繋げていると考えられている。こ のように, パフォーマンスに対する思考の内容や機能に ついては文化的背景による影響を受けることが報告され ている。「身体的回復」には項目 38 “何でも出来そうだ と感じた”など日本人からするとポジティブな側面を強 調するような表現を意味する項目が存在する。国外アス リートと比べ悲観的な認知に対する親和性が高い日本人 アスリートは, それらの項目について先験的に低く見積 もる傾向があることが推察される，本研究に打ける「身 体的回復」の $\alpha$ 係数が低かったのは, そうした文化差に よる思考や機能の違いが影響していたと考えられる.

「睡眠の質」は項目 19 “満足し, リラックスして眠りに ついた”，項目 27 “満足な睡眠がとれた”，項目 36 “熟睡 ができなかった（逆転項目），項目 46 “ちょっとした ことで目が覚めた (逆転項目)”の 4 項目によって構成 されている. 先行研究 ${ }^{2)}$ (左) と本研究 (右)に扔ける 各項目の平均值 $\pm \mathrm{SD}$ を比較すると, 項目 $19(3.07 \pm 1.52$ vs $2.92 \pm 1.61)$, 項目 $27(3.03 \pm 1.55$ vs $2.66 \pm 1.62)$, 項目 $36(4.17 \pm 1.76$ vs $3.39 \pm 1.69)$, 項目 $46(4.28 \pm 1.74$ vs 4.36 土1.55）となった，続いて，各項目が削除された場合の $\alpha$ 係数を確認すると項目 $19(\alpha=.53)$, 項目 $27(\alpha=.60)$, 項目 36（ $\alpha=.55 ）$, 項目 46（ $\alpha=.78 ）$ を示した. Cauter et $\mathrm{al}^{27)}$ は16歳〜25歳以降年齢を追うごとに徐波睡眠量 （深睡眠）が減少し, 浅い睡眠（段階 1 , 段階 2 睡眠）が 増加することを報告している。先行研究 ${ }^{2}$ (16歳〜33歳： 平均21.8歳 \pm 3.6$)$ よりも本研究の対象者の方がより年齢
が低かった（15〜23歳：平均 $19.1 \pm 1.7 ）$. 大学生特有の 睡眠習慣の乱れに加え睡眠の熟睡度における年齢差が項 目46“ちょっとしたことで目が覚めた（逆転項目）”に影 響し内的整合性を低下させたと考えられる。

「休息の妨げ」は, 項目 51 “休㦝時間中に休めなかっ た”，項目 58 “休噁の機会が少な過ぎると感じた”，項目 66 “休䚐時間中もやらなければならないことがあった”, 項目 72 “適切なタイミングで休䕀できなかった”の 4 項 目によって構成されている. 先行研究 ${ }^{2)}$ (左) と本研究 （右）に扔ける各項目の平均值 $\pm \mathrm{SD}$ を比較すると, 項目 $51(2.07 \pm 1.54$ vs $2.05 \pm 1.51)$, 項目 $58(1.55 \pm 1.67$ vs 2.64 $\pm 1.95)$, 項目 $66(1.69 \pm 1.63$ vs $2.54 \pm 1.65)$, 項目 $72 （ 1.38$ \pm 1.44 vs $2.45 \pm 1.65)$ となった，続いて，各項目が削除 された場合の $\alpha$ 係数を確認すると項目 $51 \quad(\alpha=.62)$, 項 目58 $(\alpha=.59)$, 項目 66 $(\alpha=.66)$, 項目72（ $\alpha=.53 ）$ を 示した. 小野と庄司 ${ }^{28)}$ は, 日本の部活動に扔ける先輩後 輩関係について研究した結果, 構成概念の一つとして「後 輩の仕事」(ex. 後輩は練習の準備と片づけを行っている) を見出している. 本研究は, 競技力向上を目的として活 動している運動部に所属する高校生及び大学生を対象と していた，このことから，「休息の妨げ」の内的整合性は 運動部に招ける先輩後輩関係が項目 66 “休款時間中もや らなければならないことがあった”に影響し $\alpha$ 係数を低 下させたことが推察される. 先行研究 ${ }^{2}$ ではこれらの影 響は確認されておらず,「休憩の妨げ」にみられる運動 部の先輩後輩関係の影響は日本特有のものであると考え られる。

日本版RESTQ-76 Sportの因子構造の再現性 Kellmann and Kallus ${ }^{2)}$ を参考に, 主成分分析 (varimax 回転) により英語版と同様の因子構造が認められるかを検討し た. 英語版 RESTQ-76 Sportは, 既存の一般的なストレ ス及びリカバリー尺度 $(12 \text { 尺度, 計 } 48 \text { 項目 })^{29)} に$ に, スポー ツに特有のストレス及びリカバリー尺度（7 尺度, 計 38 項目）を付加することで作成された質問紙である，従っ て, 因子構造の再現性の検討は, 英語版の分析方法にな らい一般的な尺度とスポーツに特有の尺度は分けて分析 を実施した。

一般的な尺度においては, Kellmann and Kallus ${ }^{2)}$ で示 されたような 2 因子構造が確認された。 Kellmann and Kallus $^{2)}$ の研究では, 一般的なストレス尺度（一般的ス トレス, 感情的ストレス, 社会的ストレス, 心理的葛藤/ 精神的重圧, 疲労, 活力の低下, 体調不良の訴元) と一般 的なリカバリー尺度（成功, 社会的回復, 身体的回復, 全 般的幸福度, 睡眠の質）から構成されることが示されて いる. 本研究に扔いても先行研究 ${ }^{2)}$ と同様に一般的な又 トレス尺度及びリカバリー尺度共に 40 以上の十分な負 荷量を示し，各尺度を説明し得る十分な負荷量が示され 
たと言える

一方，「睡眠の質」はストレス尺度としても高い因子 負荷量（-.52）を示した. Kellmann and Kallus ${ }^{2)}$ は, 一 般的なリカバリー尺度とされている「睡眠の質」(-.62) はストレス尺度としても十分な值が示されていることか ら，これらのリカバリー尺度はストレス要因とも関連し た尺度であることを指摘している，従って，日本版にお いても「睡眠の質」はストレスとも関連した尺度である と解釈される, 更に, 英語版では「身体的回復」(-.51)「全 般的幸福度」(-.51) がストレス尺度としても高い因子負 荷量を示しているが, 日本版に扔いては同様の結果は得 られずリカバリー尺度としてのみ高い因子負荷量を示し た．国外のアスリートと比べ，パフォーマンスに対する 悲観的な認知に対する親和性が高いと考えられる日本人 アスリートにとって ${ }^{26)}$ ，「身体的回復」や「全般的幸福度」 はより鋭敏なリカバリーの尺度として機能し得ることが 示唆された。

スポーツに特有の尺度も, Kellmann and Kallus ${ }^{2)}$ で示 されたような 2 因子構造が確認された。 Kellmann and Kallus $^{2)}$ の研究を基に, スポーツに特有のストレス尺度 （休息の妨げ, 燃え尽き/精神的な疲労困俓恶, フィットネ ス/怪我）とスポーツに特有のリカバリー尺度（フィッ 卜ネス/好調な状態, 燃え尽き/個人的達成, 自己効力感, 自己調整）から構成されることが示されている。 スポー ツに特有のストレス尺度及びリカバリー尺度共に.40以 上の十分な負荷量を示し, 各尺度を説明し得る十分な負 荷量が示されたと言える。

日本版RESTQ-76 Sportの併存的妥当性 併存的妥当性 を検討するため日本版 POMS-Sを外的基準として Pearsonの積率相関係数を算出した。そ結果，「ストレス尺 度はTMD と正の相関，活力と負の相関を示し，一方リ カバリー尺度は TMD と負の相関，活力と正の相関を示 す」という本研究の仮説を概ね支持する結果となった， これらの結果は, Kellmann and Kallus ${ }^{2)}$ の相関係数の報 告と同程度であった。 上記の結果より, 日本語版の併存 的妥当性を支持する結果となったと言える。

本研究の限界と今後の展望 最後に, 本研究の限界と今 後の展望を述べる, 本研究では, 英語版を参考に因子構 造の妥当性の検証に，因子間の合成を目的とした主成分 分析を採用した. 上記の手続きについてDavis et al. ${ }^{30)}$ は,

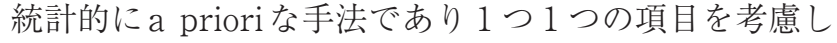
た探索的因子分析を採用し因子構造の妥当性を確認すべ きだと指摘した。実際に，Davis et al. ${ }^{30)}$ は項目を考慮 した因子分析を実施し，19尺度が確認されなかったこ とを報告している，RESTQ-76 Sportは既に出版されて いる実用的な尺度であり、リカバリーの低下を防ぐ有用
な指標であることは支持されている。しかし， Davis et al. ${ }^{30)}$ の報告にあるように妥当性基準に打いては一定の課 題を有しているため, 引き続きストレス/リカバリーを 構成する項目を検討していく必要があるだろう。また, 本研究の結果より日本版の信頼性（ $\alpha$ 係数）において日 本人特有の思考や機能，文化的背景の違いなどが影響す ることが明らかとなった，本研究では，国際比較などの 観点から尺度を構成する項目を維持することを前提に検 討を進めたが，将来的には日本人特有の文化や思考特性 などを考慮したリカバリーの尺度による研究の発展も望 まれる，さらに，本研究で作成した日本版は19尺度 76 項 目となり，より多面的にストレスリカバリーの程度を 評価可能という利点はあるが，項目数が多いため回答へ の負担が大きいという課題も有している，現在，英語版 の RESTQ-Sportは12尺度36項目の短縮版が開発され ており, その信頼性・妥当性も確かめられている ${ }^{19)}$. 今後, 定期的に測定するモニタリング指標として沉用性を高め るには短縮版の作成も急務である。

\section{まとめ}

本研究では, 日本版 RESTQ-76 Sportの作成及び信頼 性・妥当性の検証を行った。その結果，概ね Kellmann and Kallus $^{2)}$ の報告と一致する結果となり，実用的に使 用可能な信頼性・妥当性が確認された。本邦では，心理 学的なリカバリー研究は殆ど進められていない. 従って, 本研究の知見は国内に扮けるリカバリー研究の推進に寄 与するものと考えられる。

利益相反自己申告：申告すべきものはなし

\section{謝 辞}

法政大学の木下訓光教授, Nanyang Technological Universityの川端雅人教授，大阪体育大学のウエイン・ジュリ アン教授には，翻訳作業及び項目精査の際に多くの助言を 頂きました。ここに感謝の意を表します。

\section{引用文献}

1) Kellmann M. Preventing underperformance in athletes. In: Enhancing recovery, Human Kinetics, Champaign, IL, 2002.

2) Kellmann M, Kallus KW. The Recovery-Stress Questionnaire for Athletes: user manual, Champaign, IL, Human Kinetics, 2001.

3）長谷川博, 山本利春(監訳), リカバリーの科学 - スポー ツパフォーマンス向上のための最新情報－第 1 版, 有限 会社ナップ, 東京, 2014.

4）山本利春（監訳），リカバリーーアスリートの疲労回復 のために一第 1 版, 有限会社ナップ, 東京, 2013.

5) Kellmann M. Preventing overtraining in athletes in high-intensity sports and stress/recovery monitoring. 
Scand J Med Sci Sports 20: 95-102, 2010.

6) Kellmann M, Altenburg D, Lormes W, Steinacker JM. Assessing Stress and Recovery during Preparation for the world championships in Rowing. Sport Psychol 15: 151-167, 2001.

7) Kellmann M, Günther KD. Changes in stress and recovery in elite rowers during preparation for the Olympic Games. Med Sci Sports Exerc 32: 676-683, 2000.

8) Kellmann M, Kölling S, Hitzschke B. The Acute Measure and the Short Scale of Recovery and Stress for Sports: Manual, Sportverlag StrauB, Germany, 2016.

9) Hitzschke B, Kölling S, Ferrauti A, Meyer T, Pfeiffer M, Kellmann M. The Recovery and Stress Scale for Sports (SRSS). Z Sportpsychol 22: 146-161, 2015.

10) Hitzschke B, Holst T, Ferrauti A, Meyer T, Pfeiffer M, Kellmann M. Development of the Acute Recovery and Stress Scale. Diagnoustica 62: 212-226, 2016.

11) Laurent CM, Green JM, Bishop PA, Sjökvist J, Schumacker RE, Richardson MT, Curtner-Smith M. A practical approach to monitoring recovery: developing of a perceived recovery status scale. J Strength Cond Res 25: 620-628, 2011.

12）横山和仁, 下光輝一, 野村 忍 (編), 診断・指導に活かす POMS 事例集, 金子書房, 東京, 2002.

13）横山和仁 (編), POMS 短縮版手引と事例解説, 金子書房, 東京, 2005.

14）島本好平, 東海林祐子, 村上貴聡, 石井源信 : アスリート に求められるライフスキルの評価一大学生アスリート を対象とした尺度開発一, スポーツ心理学研究, 40: 1330, 2013.

15) Morgan WP, Brown DR, Raglin JS, O'Connor PJ, Ellickson KA. Psychological monitoring of overtraining and staleness. Br J Sports Med 21: 107-114, 1987.

16) Carskadon MA. Patterns of Sleep and Sleepiness in Adolescents. Pediatrician 17: 5-12, 1990.

17）竹内朋香, 犬上 牧, 石原金由, 福田一彦：大学生におけ る睡眠習慣尺度の構成および睡眠パタンの分類, 教育心
理学研究, 48: 294-305, 2000.

18）文部科学省. 大学分科会（第 108 回）・大学教育部会（20 回）合同会議（2012年 7 月 24 日）配付資料 資料3-2 関 連データ (2/2)「学生の学修時間の現状」, 2012.

19) Kallus KW, Kellmann M. The Recovery-Stress Questionnaires: User Manual. Pearson Assessment \& Information GmbH, Frankfurt, 2016.

20）倉藤利早, 田島 誠, 米谷正造：指導者のリーダーシップ のタイプが選手の自主性に及ぼす影響, 川崎医療福祉学 会誌, 20: 457-460, 2011.

21）井上史子, 沖 裕貴, 林 徳治：中学校における自主性尺度 項目作成の試み, 教育情報研究, 21: 13-20, 2006.

22）高田利武：日本文化における相互独立性・相互協調性 の発達過程 - 比較文化的・横断的資料による実証的検 討 - , 教育心理学研究, 47: 480-489, 1999.

23）小倉一哉: 日本の長時間労働 - 国際比較と研究課題, 日 本労働研究雑誌, 575: 4-16, 2008.

24）スポーツ庁. 平成 28 年度全国体力・運動能力・運動習 慣等調査, 2016.

25) Peters HJ, Williams JM. Moving cultural background to the foreground: An investigation of self-talk, performance, and persistence following feedback. J Appl Sport Psychol 18: 240-253, 2006.

26）有富公教, 外山美樹：日本人アスリートの競技中に生じ る思考の構造および発生傾向の検討, スポーツ心理学研 究, 42: 1-14, 2015.

27) Cauter VE, Leproult R, Plat L. Age-related changes in slow wave sleep and REM sleep and relationship with growth hormone and cortisol levels in healthy men. JAMA 284: 861-868, 2000.

28）小野雄大, 庄司一子：部活動における先輩後輩関係の研 究一構造, 実態に着目して - , 教育心理学研究, 63: 438452, 2015.

29) Kallus KW. The Recovery-Stress Questionnaire, Swets \& Zeitlinger, Frankfult, 1995.

30) Davis H, Orzeck T, Keelan P. Psychometric item evaluations of the Recovery-Stress Questionnaire for athletes. Psychol Sport Exerc 8: 917-938, 2007. 